\title{
The Enforcement Role Of The Companies' Commission Of Malaysia
}

\author{
Mohd-Haswadi Hassan, Suruhanjaya Syarikat, Malaysia \\ Glen D. Moyes, University of Texas - Pan American, USA \\ Zuraidah Mohd-Sanusi, Universiti Teknologi MARA, Malaysia \\ Takiah Mohd Iskandar, Universiti Kebangsaan, Malaysia
}

\begin{abstract}
This paper explores the role of the enforcement efforts undertaken by the Companies Commission of Malaysia (CCM) as a regulator of the Companies Act of 1965, which is entrusted to uphold and ensure good practices of corporate governance among Malaysian companies. The paper attempts to provide an understanding on various enforcement actions in terms of the effectiveness and adequacy of the measures adopted by the CCM in promoting and improving the level of corporate governance practices in Malaysia. CCM has adopted the Balanced Enforcement Approach to promote effective corporate governance practices among the Malaysian companies. An increasing compliance rate and greater corporate governance awareness at a level similar to other countries indicates at least a minimum success of the Balanced Enforcement Approach. Indicated is the need for CCM to establish a benchmarking or ranking procedure in order to determine the level of corporate governance practices among companies in Malaysia.
\end{abstract}

Keywords: Corporate Governance, Enforcement, Compliance, and Surveillance

\section{INTRODUCTION}

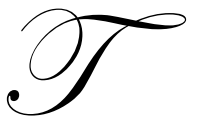

he 1997 economic crisis has resulted in a considerable effort implemented by the Malaysian government to develop a comprehensive framework for establishing good practices of corporate governance. After the establishment of the framework of good practices of corporate governance, there remained some concerns over the effectiveness of corporate governance rules arising from the increasing number of corporate misconduct cases in Malaysia (Sarji, 2007). A corporate misconduct represents noncompliance of written rules or the lack of actions taken on fraudulent activities committed within the internal control system. A weak enforcement environment of the government regulators has aggravated difficult for firms to comply with the requirements for achieving good practices of corporate governance. The lack of enforcement of regulations and laws is the key problem that needs to be corrected with a strict enforcement measure of each noncompliant corporate case (Johnson, 2003).

The Companies Commission of Malaysia (CCM) is a government agency that actively advocates the practice of good corporate governance and integrity among companies in Malaysia. Under the Companies Act 1965, the role of CCM is to regulate corporations in this country. The CCM is also empowered by the Companies Act 1965 to provide services in administering, collecting and enforcing payments of prescribed fees or any other charges under the prescribed act and the jurisdiction of CCM. This paper seeks to understand the enforcement actions taken by CCM in enhancing corporate governance and the integrity of Malaysian companies. The paper further explores extent by which the CCM administers the enforcement of corporate governance and integrity upon corporations in Malaysia.

This paper provides an insight into the role of CCM that has become very important as a result of the financial scandals among companies, such as Perwaja and Malaysian Airlines, which occurred during the 1997 financial crises in Malaysia. The increasing trend of corporate misconduct and fraudulent actions committed by directors and senior management personnel of the companies and non-compliance with the rules of corporate 
governance became evident. In this paper, the information may be used as a basis to determine the level of adequacy and effectiveness of the enforcement initiatives implemented by CCM. CCM has the responsibility to promote and create a business environment that is more conducive to effective business practices in Malaysia. Other than Malaysia, corporate governance has also been enacted as a law in different countries, such as the United Kingdom (UK), Hong Kong, Singapore, and New Zealand.

The remainder of this paper discusses corporate governance, the Enforcement Division of CCM, and the enforcement activities adopted by CCM.

\section{CORPORATE GOVERNANCE AS A LAW}

The concept of corporate governance began with the issuance of several reports such as the U.K. Cadbury Report on the Financial Aspect of Corporate Governance issued in 1992, the report of the Greenberg Committee on Director Remuneration issued in 1995, and the Hampel Committee on Corporate Governance issued in 1998 (Malin, 2003). The Cadbury Report on the Financial Aspect of Corporate Governance defined corporate governance as "[T] he whole system of controls, both financial and otherwise, by which a company is directed and controlled". The Cadbury Report definition of corporate governance is based on the key corporate governance problems arising from the separation of ownership of shareholders and control by the management. The definition of stakeholders is established by law to include investors, employees, creditors and suppliers (Mason and O'Mahony, 2008). The expectation of these stakeholders concerning the wealth-creating capacity of companies requires good corporate governance. Good corporate governance is not only driven by compliance or regulatory requirements but is very important as a means for companies to improve their performance, competitiveness and sustainability (Webb, 2006).

The Organization for Economic Cooperation and Development (OECD) defines corporate governance as "[A] set of relationships between a company's board, its shareholders and other stakeholders. It also provides the structure through which objectives of the company are set, and means of attaining those objectives and measure of monitoring performance are determined" (OECD 1999, 2004). The OECD identifies a comprehensive corporate governance framework, which includes the elements of rights and obligations of shareholders, the equitable treatment of shareholders, the role of stakeholders and corporate governance, transparency, disclosure of information and audit, the functions of boards of directors, non-executive members of the board and executive management, and compensation and performance.

The UK has enacted a law requiring corporate governance to be implemented by publicly held companies. In general, similar principles of corporate governance of the UK have been adopted in Malaysia. The non-statutory self-regulatory Malaysian Code on Corporate Governance (Code) is almost identical to the original combined Code of the UK, and is crisis-driven (Shim, 2006). The codes in these two countries are meant to assist companies in achieving higher standards of corporate governance based on the principles and best practices on structures and processes of corporate governance. In Malaysia, the corporate governance practices are intended to be selfregulatory to promote compliance with good intentions and high spirits in order to set a higher standard and encourage a greater respect for law (Shim, 2006). Malaysia has adopted a corporate model based on the single-tier or unitary board, which is similar to that in the UK. In a single-tier or unitary board model, there is no separation between the supervisory and management functions of the board. Under the model, the board comprises executives and non-executive directors.

\section{THE CORPORATE GOVERNANCE LEGISLATION IN MALAYSIA}

Malaysia approved a major amendment to its corporate legislative governance framework more than two decades ago. Following the calls for more transparency and accountability and to be more internationally competitive, Malaysia has continued its efforts to support the adoption of the best practice of corporate governance. The principal enforcement of the corporate governance is assigned to a number of agencies, including the Securities Commission, Bursa Malaysia (formerly known as the Kuala Lumpur Stock Exchange (KLSE), the Central Bank (Bank Negara Malaysia), the Malaysian Anti-Corruption Commission (MACC), and the Companies Commission of Malaysia (CCM). The amendment of the framework involves several laws passed by Parliament to govern the desired practices of corporate governance in Malaysian companies. The underlying spirit of the amendment is that 
good corporate governance should promote the appropriate use of resources, and safeguarding assets and the protection of rights of all stakeholders, including the ultimate objective of increasing the worth of the company in an effective and efficient manner (Rahman, 2006). Figure 1 presents the nine components of the Malaysian corporate governance legislative framework.

Figure 1: The Corporate Governance Legislative Framework

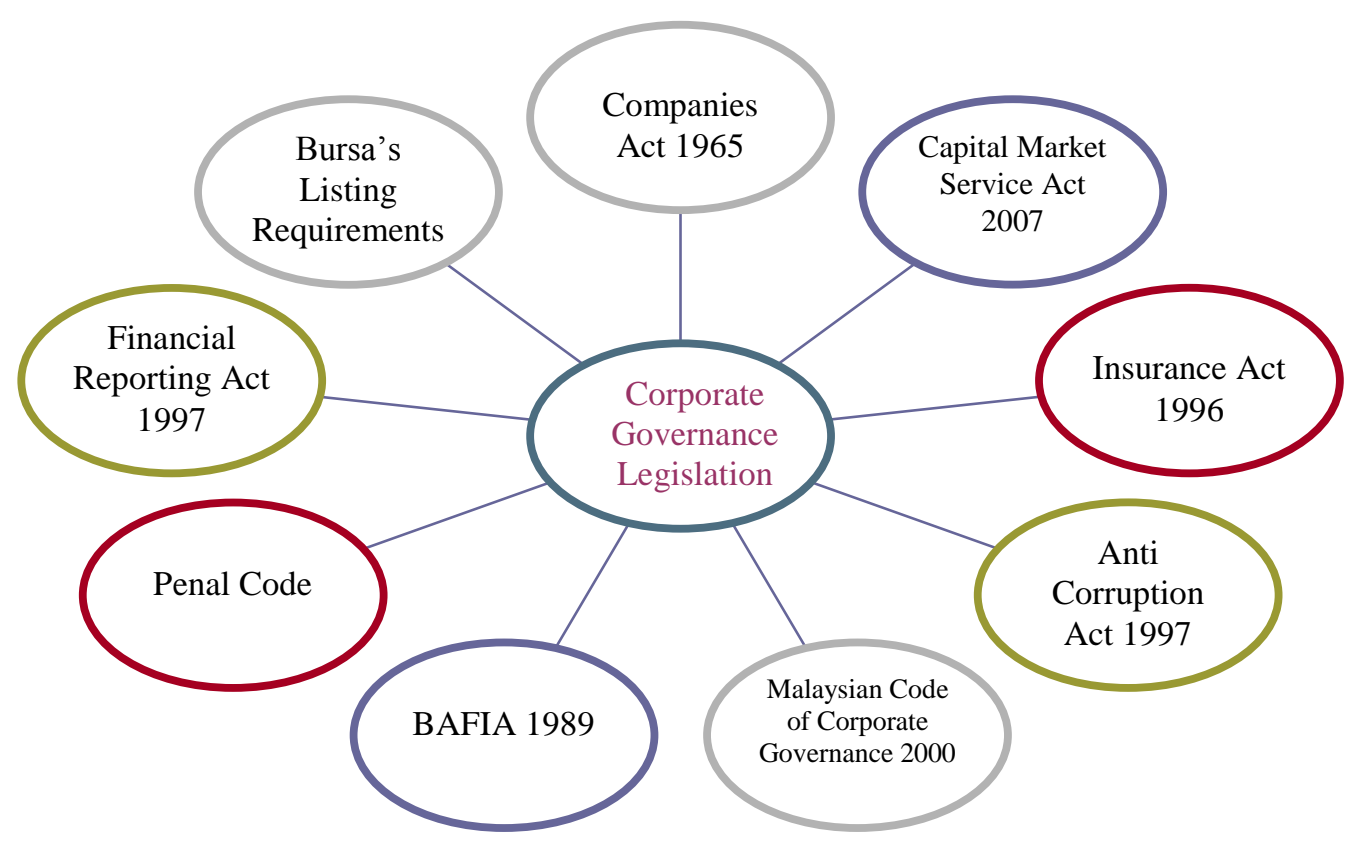

Source: CCM Training Academy (2008)

The amount of legislative and administrative activities involved in the reformation of Malaysian corporate law during the last decade exceeds the total amount of corporate law reforms instituted prior to that period since Malaysia received its independence in 1957 (Shim, 2006). One of the major components with a significant influence on the Malaysian corporate governance landscape is the Malaysian Code of Corporate Governance. The Code was first issued in March, 2000. The Code specifies the principles and best practices of good corporate governance. It also describes structures and internal processes of optimal corporate governance practices. In 2007, the Code was revised being one of the continued collaborative efforts between the Malaysian government and other corporations. The reform covers the inclusion of the Principles of Corporate Governance, which becomes the best practices and principles for corporations.

In 2007, the government amended the Companies Act 1965, which also involves the Malaysian corporate governance legislative framework. This amendment affects both publicly listed companies and other types of companies incorporated under the Companies Act 1965. Corporate governance is the main theme of the amendment that covers the duties and responsibilities of directors and obligations for disclosures of transactions involving directors. The Amended Act also provides statutory recognition for the functions and powers of the board of directors. It extends the definition of directors to include individuals who are primarily responsible for the operations and financial management of the companies. The Act classifies the following individuals as directors: Chief Executive Officer (CEO), Chief Financial Officer (CFO) and Chief Operating Officer (COO). The amendment requires a major improvement in the level of transparency and accountability among company directors and officers (Rahman, 2006). 
The adoption of a universally acceptable framework of corporate governance in Malaysia represented a catalyst for the improvement and enhancement of foreign investors' confidence. The framework is expected to strengthen the corporate governance, which in turn attracts foreign capital investments in Malaysian corporations (Sarji, 2007). In contrast, poor corporate governance would discourage and negatively affect the foreign direct investment and lead to bad business practices. These bad practices will cause bias, manipulation, chaos, and fraud rather than independence, fairness, accountability, transparency and integrity by corporations (Sarji, 2007). The new legislation and corporate codes provide a platform in enhancing Malaysia's ability to attract foreign investments (Devi, 2003). These recent developments are expected to strengthen the corporate governance legislative framework, to improve the level of transparency and accountability among directors, and to enhance market freedom and investment protection.

Another milestone of corporate governance reformation in Malaysia was the establishment of a Corporate Law Reform Committee (CLRC) by the CCM in December 2003. The committee undertook a comprehensive and holistic review of corporate law in Malaysia instead of performing reviews on a piece-meal basis. The comprehensive review brings about clarity and consistency of company law for Malaysia that is at par with other leading common-law jurisdictions, such as the UK, Singapore and Australia (Shim, 2006). This company law reform initiative is based on the UK Company Law Review-Modern Company for Competitive Economy and the Singapore Company Legislation and Regulatory Framework Committee. Although the CLRC has not been organized yet, the CCM itself has undergone a major transformation in its role and duties, especially in the role of enforcement on companies. The following section discusses the details of CCM roles and activities in enhancing its regulatory functions on companies in Malaysia.

\section{THE ENFORCEMENT DIVISION OF CCM}

CCM came into operation on 16 April, 2002 as a result of a merger between the Registrar of Companies (ROC) and the Registrar of Businesses (ROB) in Malaysia. The formation of ROC by the Malaysian government in 1898 marked the history of business registration in this country. All companies incorporated in Malaysia, then under the Companies Act 1965, must be registered with ROC, a body which has the regulatory role over those companies. ROB was established in 1939 and is responsible for the registration of other businesses, which include sole proprietorships and partnerships. Upon the consolidation of both the ROC and the ROB, Malaysia then approved the Companies Commission of Malaysia Act by Parliament in 2001. As a result, CCM was formed as a statutory body that regulates companies and businesses in Malaysia. CCM is empowered to undertake the necessary actions in connection with the performance of functions under Section 17 of Companies Commission of Malaysia Act 2001. The main activity is to incorporate companies and register businesses and to provide information about companies and businesses to the public. CCM is an agency under the Ministry of Trade and Consumer Affairs. The agency comprises commission members who are appointed by the Minister of Trade and Consumer Affairs. The commission members are assigned the role of monitoring CCM activities and performance. They are also responsible for setting and governing the direction of the CCM. As the leading authority for the improvement of corporate governance, $\mathrm{CCM}$ has to fulfill its functions to ensure compliance with business registration and corporate legislation through comprehensive enforcement and monitoring activities to sustain positive developments in the corporate and business sectors of the Nation.

The total number of companies registered with CCM as at December 31, 2007 was 799,582. On average, the number of registered companies has increased by approximately 4,000 per year, representing an increase of about 5 percent per year since 2004. The increase has helped sustain a steady economic growth for Malaysia (CCM Annual Report, 2007). A total of 21,353 inactive companies have been removed from being registered with CCM in 2007. The removal of the companies by CCM was authorized under Section 308 of the Companies Act 1965. Figure 2 shows the number of companies incorporated in Malaysia from 2004 to 2007. 
Figure 2: Number of Companies Incorporated in Malaysia

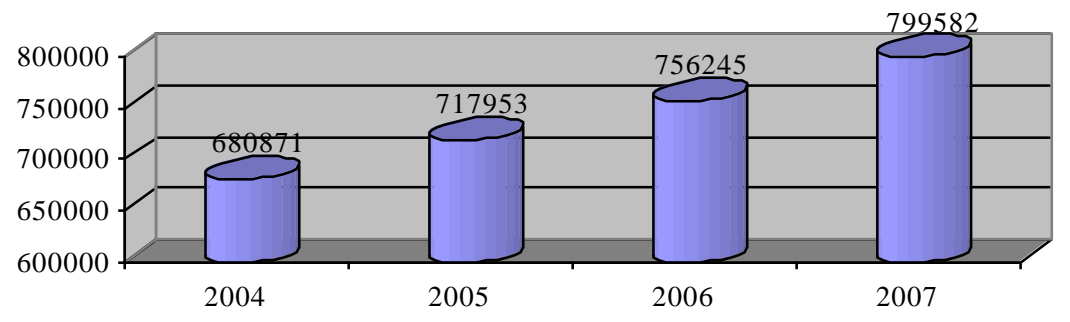

Source: CCM 2007 Annual Report

The Enforcement Division of CCM has the responsibility of planning, monitoring and executing all aspects of the enforcement activities conducted by CCM. The Enforcement Division is divided into three different subdivisions: Compliance, Investigation, and Legal Services. Table 1 shows the details of the functions of each subdivision.

Table 1: Enforcement Division of CCM

\begin{tabular}{|c|c|}
\hline Sub-Division & Function \\
\hline 1. Compliance & $\begin{array}{l}\text { - To enhance the level of the compliance rate among companies by } \\
\text { encouraging good corporate governance practices. }\end{array}$ \\
\hline \multicolumn{2}{|l|}{ 2. Investigation: } \\
\hline - $\quad$ Financial \& Fraud & $\begin{array}{l}\text { - To investigate cases related to the protection of minority shareholders, } \\
\text { consumer protection, forensic accounting, insolvent trading, and fraudulent } \\
\text { investment. }\end{array}$ \\
\hline - Corporate Governance & $\begin{array}{l}\text { - To investigate cases of due diligence, breach of director fiduciary duties, } \\
\text { corporate fraud, false and misleading information, cases on insolvency, } \\
\text { related parties' transactions and failure on non-disclosure cases. }\end{array}$ \\
\hline - $\quad$ Special & $\begin{array}{l}\text { - To handle cases involving public interests and national security, ministerial } \\
\text { decree, intelligence and anti-money laundering offenses. }\end{array}$ \\
\hline - $\quad$ General Offenses & $\begin{array}{l}\text { To look into cases of non-submission of annual returns, failure to disclose } \\
\text { statutory records, and non-tabling of accounts. }\end{array}$ \\
\hline $\begin{array}{l}\text { 3. Legal Services (prosecution and civil } \\
\text { litigation) }\end{array}$ & - To prosecute offenses and provide civil enforcement. \\
\hline
\end{tabular}

For CCM, the term enforcement is defined as a different approach in the law enforcement of corporate governance. This enforcement embraces all aspects and efforts undertaken toward ensuring compliance with laws and regulations by corporations in Malaysia. The enforcement approach adopted by CCM is known as the "Balanced Enforcement" (The Star, October 2007). In 2006, the concept of "Balanced Enforcement" included proactive conventional enforcement initiatives, such as investigations, inspections, prosecution of offenses and issuances of reprimand letters. In addition, the "Balanced Enforcement" also includes the CCM Training Academy, which provides continuous education and awareness initiatives to directors and officers of corporations (CCM Annual Report, 2007).

The CCM Training Academy was established in 2007 and is known as COMTRAC. This academy comprises four centers: 1) Center for International programs, 2) Corporate Development Center, 3) Internal Development Center, and 4) Administrative and Resources Center. The CCM Training Academy is responsible for planning, developing, conducting the training programs, and conducting research programs. The objective of the 
Training Academy is to become a premier learning institution in educating the corporations and the general public concerning the various aspects of conducting business, which includes understanding corporate and business laws. The two programs under the CCM Training Academy or COMTRAC are (1) the Corporate Director Training Program (CDTP) and (2) the Licensed Secretary Training Program (LSTP). These two programs were designed to enhance the level of knowledge and competency of the company secretaries and board of directors with respect to their roles and functions.

CCM promotes education and knowledge in achieving the goals of effective corporate governance. In order to maximize compliance, the CCM attempts to utilize conventional enforcement methodologies through criminal sanctions with an increased awareness of the prohibitions and obligations imposed by the rules and legal framework. CCM defines enforcement as ensuring compliance with laws and, to this end, develops educational programs to create a greater general awareness among corporations, professionals and the general public. The CCM Training Academy conducts seminars and conferences on understanding of compliance and awareness of good corporate governance practices.

Authors have carried out a study on the enforcement activities of CCM by collecting data from various CCM divisions including the (1) Compliance Division, (2) the Investigation Division, (3) the Legal and Services Division, and (4) the Training Academy. The objective of the study is to assess the progress of the CCM enforcement initiatives and to determine the CCM achievement of implementing the initiatives effective. Data are analyzed using trend analyses and other quantitative measures to determine the effectiveness and adequacy of the $\mathrm{CCM}$ enforcement practices. In addition, interviews were conducted to gather information on the experience and expertise of key CCM personnel. Results of the analyses of data from the enforcement activities and the interviews were used as a basis for assessing the progress of the CCM enforcement initiatives and for determining whether any progress has been made toward achieving effectiveness by the CCM. The following sections report results of the analyses.

\section{THE ENFORCEMENT ACTIVITIES OF CCM}

In order to achieve a balanced enforcement of good practices of corporate governance, CCM has adopted a number of enforcement activities. The enforcement activities utilize both education and legal sanctions. The activities are assigned to three CCM divisions, which are: 1) the Compliance Division, 2) the Investigation Division, and 3) the Legal and Services Division. The Compliance Division conducts physical inspections of the companies. The Investigation Division is responsible for investigating breaches of possible offenses under the Companies Act 1965. The Legal and Services Division is entrusted with the responsibility of handling all the legal matters and prosecutions of court cases. In addition, CCM conducts workshops for companies through the CCM Training Academy (COMTRAC) on different areas relating to the running of corporations with the objective of enhancing their understanding of the best practices of corporate governance.

\section{Physical Inspection by the Compliance Division}

The physical inspection of companies represents routine activities being performed by the CCM enforcement officers. During the inspection, accounting documents and records are verified to ensure the reliability of financial statements of corporations. Inspections are conducted on the CCM database containing the corporate information, to investigate non-compliance to provide reliability in the corporate statutory documents. Reports of the inspections of the company's statutory books are recorded at the registered offices in compliance with the Companies Act 1965.

Figure 3 shows the number of cases of companies being investigated due to noncompliance with the requirements of Companies Act of 1965 from 2005 to 2007. The cases are identified by both the Surveillance Section and the Corporate Account Monitoring Section of the CCM and referred to the Compliance Division for inspection. The number of staff in both CCM sections has been increased, which enables CCM to increase the number of inspections. Figure 3 presents the number of physical inspection conducted by the Compliance Division for the years 2005 to 2007 . The figure shows that the number of inspections has increased significantly approximately ten times from 2005 to 2006 and four times from 2006 to 2007. 
Figure 3: Comparison of Inspections Conducted

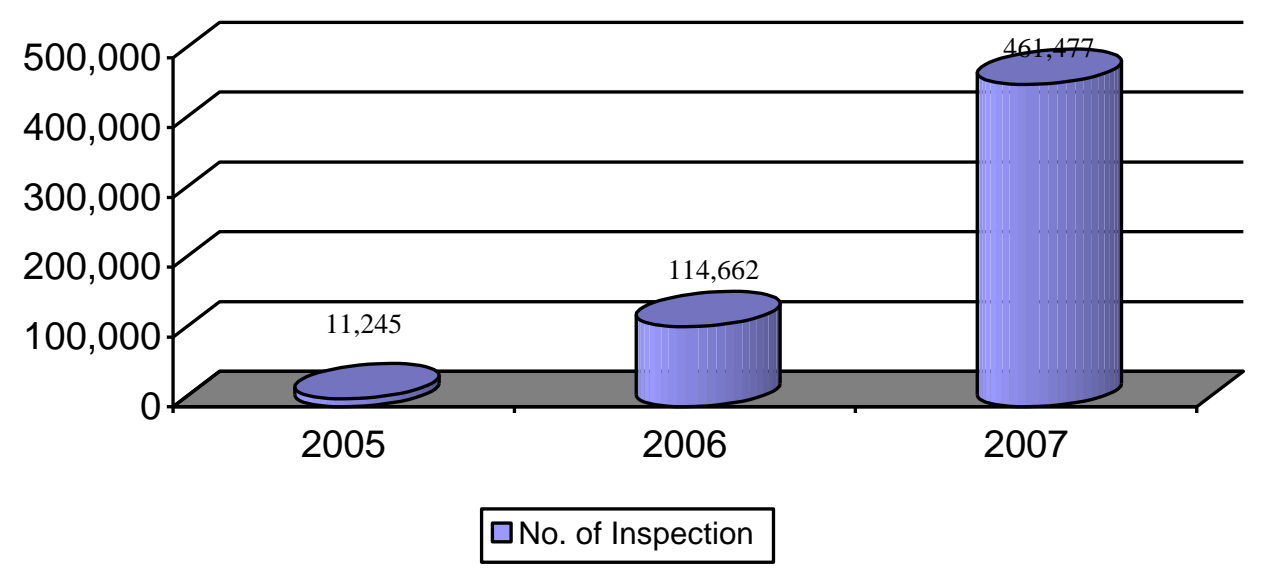

Source: CCM Compliance Division

Table 2 shows the number of penalty notices issued by the CCM to corporate officers for failing to comply with the requirements of company law for the year 2007. The penalty notices issued by the CCM for the noncompliance are classified into eight different categories in accordance with the provision under the Malaysian law involving noncompliance offenses. Table 2 shows that the majority of the penalties issued is for the offense of failing to table account at the annual general meeting (i.e., 77.89 percent). The second most frequent noncompliance offense is failure to submit annual return (12.4 percent), followed by failure to hold an annual general meeting (9.11 percent). Overall, it is concluded that most of the offenses committed by companies relate to the completion of financial statements for submission to CCM and presentation at the annual general meeting in accordance with the legal requirements

Table 2: Penalty Notices Issued for Offenses under the Companies Act 1965

\begin{tabular}{|l|l|r|r|}
\hline \multicolumn{2}{|c|}{ Offenses under Companies Act 1965 } & \multirow{2}{*}{ Cases } & \multirow{2}{*}{ Percentage } \\
\hline Section & Descriptions & 77 & 0.09 \\
\hline $121(1)(b)$ & Failure to print Co. Name and No. in official documents & 155 & 0.18 \\
\hline $121(3)$ & Failure to display Company Name & 7,789 & 9.11 \\
\hline $143(1)$ & Failure to hold Annual General Meeting & 10,604 & 3 \\
\hline $165(4)$ & Failure to submit Annual Return & 66,590 & 12.40 \\
\hline $167(1)$ & Failure to keep accounting record for seven years & 174 & 0.00 \\
\hline $169(1)$ & Failure to table account at the Annual General Meeting & 101 & 0.23 \\
\hline $169(4)$ & Failure to table audited account at Annual General Meeting & 85,493 & 0.12 \\
\hline $364(2)$ & Making false and misleading statements & 100.00 \\
\hline Total & & & \\
\hline
\end{tabular}

Source: CCM 2007 Annual Report

As a result of non-compliance with the statutory requirements, companies are issued with a penalty or fine. Figure 4 shows the number of penalties or fines issued to companies that committed noncompliance offenses from 2004 to 2007. Each year, about 130,000 penalties are issued, except for 2006 where the number of penalties was lower $(112,017)$. This figure indicates that companies paid a substantial amount of penalties or fines to the CCM. The total amount of penalties or fines collected in 2007 was RM 69.86 million each year. 
Figure 4: Trend Analysis of Number of Penalties Issued

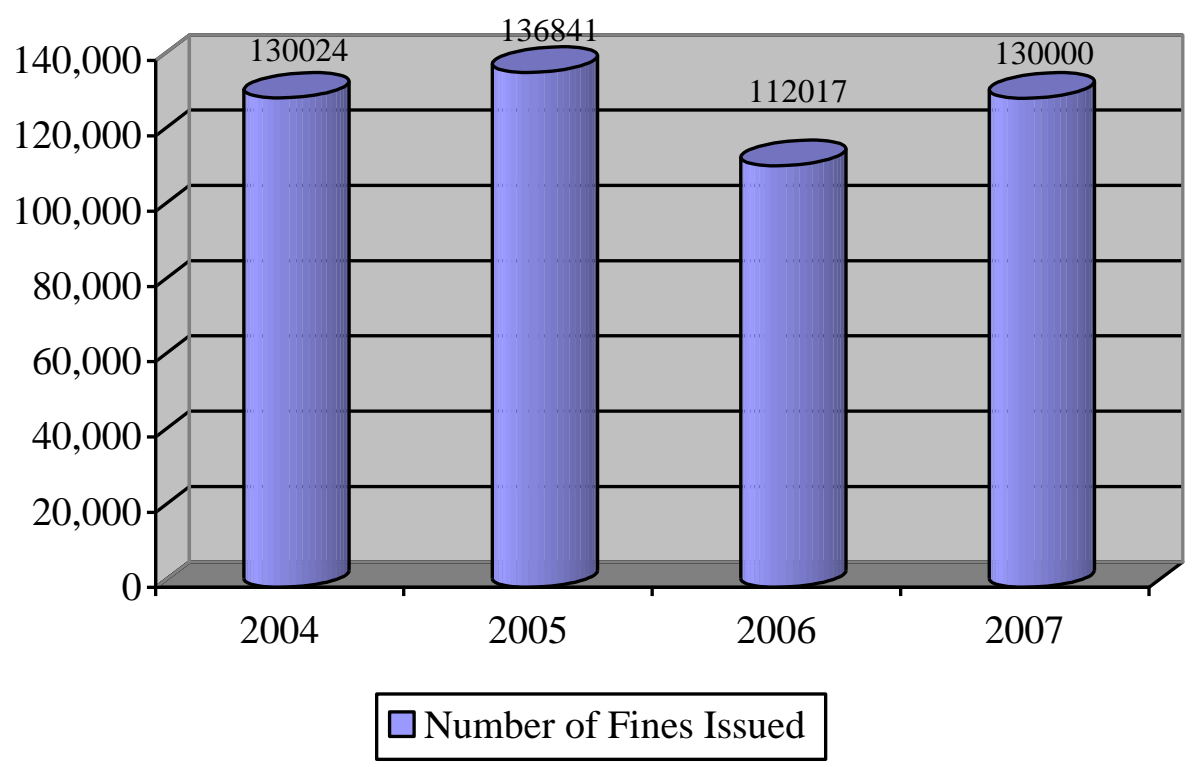

Source: CCM 2007 Annual Report

\section{Investigation of Breaches by the Investigation Division}

Since the inception of CCM in 2003, the number of cases of corporate misconduct reported to the general public has increased. As a result, CCM's investigation capacity and capabilities were expanded. CCM has gone through an extensive restructuring in the Investigation Division. The Investigation Division consists of four sections: 1) Financial and Fraud, 2) Corporate Governance, 3) Special Investigation, and 4) General Offenses. Figure 5 shows that the total number of investigation papers opened increased 1.9 times from 2006 to 2007 . The total number of investigation papers completed in all sections increased by 3.8 times from 2006 to 2007.

In 2007, 42 cases involving serious breaches of good practices of corporate governance were investigated, out of which 31 cases were related to offenses concerning fiduciary duties of directors and officers of companies. CCM investigated 69 other cases involving fraud and financial reporting, of which 62 involved offenses concerning false and misleading statements. In addition, 102 cases were investigated under general offenses, of which 75 cases involved bankruptcies not discharged. In summary, 96 out of the 152 cases were prosecuted and these cases were completed in 2007.

Depending on the different types of offenses and complexity of the nature of the offenses committed, the time required to investigate each case varied. For simple offenses committed under Section 125, the average time taken was two months. In contrast, complicated investigations under Section 132 would normally take more than six months.

The cases prosecuted under the breaches of corporate governance are shown in Table 3. In 2007, the number of prosecutions increased significantly from 2006 and 7,626 cases were prosecuted for various offenses under the Companies Act 1965, in which 82 officers and directors of companies were charged with offenses regarding breaches of corporate governance. 
Figure 5: Investigation Paper (IP)

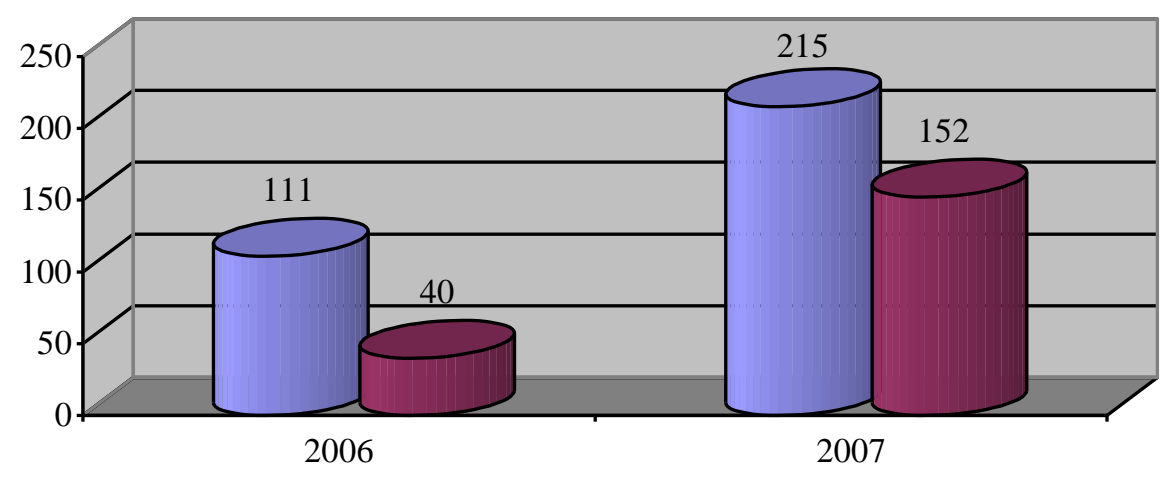

\section{$\square$ IP Opened $\square$ IP Completed}

Source: CCM Investigation Division

Table 3: Corporate Governance Offenses Prosecuted

\begin{tabular}{|c|l|c|}
\hline $\begin{array}{c}\text { Section Under } \\
\text { Companies Act 1965 }\end{array}$ & \multicolumn{1}{|c|}{$\begin{array}{c}\text { Corporate Governance Offenses } \\
\text { Under Companies Act 1965 Prosecuted. }\end{array}$} & $\begin{array}{c}\text { No. Of } \\
\text { Cases }\end{array}$ \\
\hline $364(2)$ & Companies making false/misleading statements to the CCM. & 31 \\
\hline $125(1)$ & Un-discharged bankrupt involving directors for the companies & 44 \\
\hline $169(14)$ & $\begin{array}{l}\text { Failure to give a true and fair view of the state of affairs of the company in the } \\
\text { financial statement }\end{array}$ & 2 \\
\hline $167(1)$ & Failure to keep accounting records for seven years & 4 \\
\hline $133 \mathrm{~A}$ & Prohibition of granting a loan to a person connected to the director of the company & 1 \\
\hline
\end{tabular}

Source: CCM 2007 Annual Report

\section{Corporate Director Training Program}

The CCM Training Academy (COMTRAC) has developed a program known as Corporate Director Training Program (CDTP). The CDTP provides ongoing programs to all directors and officers of Malaysian corporations. These programs are dedicated to achieving effective practices of corporate governance. Table 4 shows four modules of CDTP offered by the COMTRAC. These four modules were designed and dedicated to providing guidelines and instructions to directors and officers of Malaysian corporations on effective practice of corporate governance.

All of the training programs were organized and supervised by the CCM Training Academy. This academy is responsible for providing the training programs for company directors and officers, professionals, corporations and the general public pertaining to corporate law and corporate governance practices.

Table 4: CDTP Modules

\begin{tabular}{|c|l|}
\hline Module & \multicolumn{1}{|c|}{ Details } \\
\hline 1 & The Role and Responsibilities of Company Directors \\
\hline 2 & The Laws and Practices for Company Meetings \\
\hline 3 & The Common Offenses Committed by Company Directors \\
\hline 4 & The Understanding and Application of Corporate Governance \\
\hline
\end{tabular}

Source: COMTRAC, 2008 
The main objectives of providing the four modules of the CDTP are providing knowledge concerning the understanding of the role and responsibilities of the directors and officers. Generally, the modules provide understanding of the rights and limitations of directors and proper conduct in board and general meetings. The modules were designed to enhance the directors' knowledge of corporate law and regulations and awareness of common offenses committed by company directors, as well as the consequential penalties charged to directors committing the offenses. In addition, the modules promote the understanding and application of good corporate governance, which involves moral and ethical obligations upon company directors and officers.

Figure 6 indicates the number of directors attending CDTP programs and the number of CDTP programs provided by the CCM training centre. During the period 2005 to 2007, the number of directors attended CDTP increased significantly. Similarly, the programs offered for the training programs have also increased in order to cater the need of companies.

Figure 6: Directors' Attendance and CDTP Programs Offered

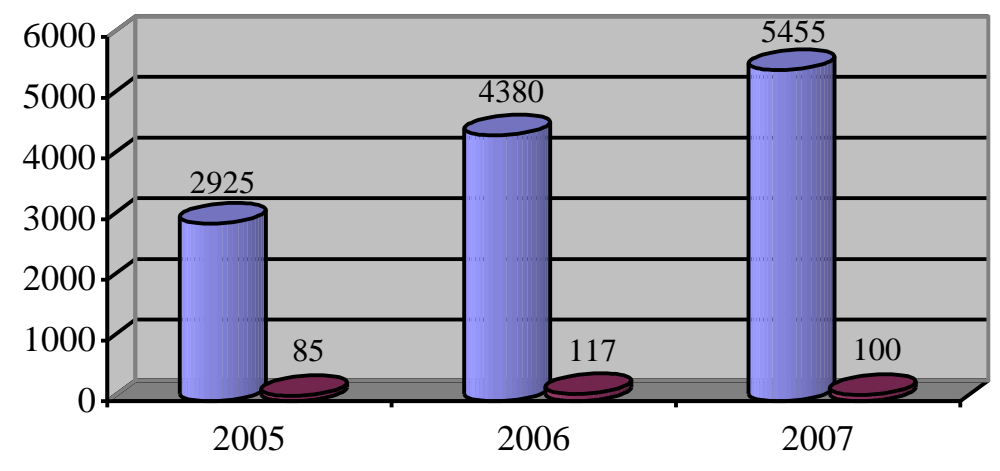

$\square$ Directors Attending $\square$ Programs Offered

Source: COMTRAC report on CDTP Program 2008

Since 2005, the number of directors who attended the CCM training programs has been extremely low, as indicated in Figure 6. The number of directors attending programs represents 0.6 percent of the total number of directors associated with the companies registered with the CCM. During the years 2005 to 2007, the overall percentage of directors attending the courses was extremely low when compared to the total number of companies registered with CCM.

\section{Reporting by Companies}

Transparency is a very significant dimension of company reporting. It refers to the timely disclosure of adequate, clear and comparable information concerning financial performance, governance, ownership and activities of the corporations. Transparency and its requirements were codified under Section 169 of the Companies Act 1965 in Malaysia. Section 169 specifically requires that all companies registered with the CCM submit their annual returns and the audited company accounts to the CCM at least once a year. Failure to submit the returns and audited accounts to CCM may result in the company's being subjected to penalties. These penalties result in either payment of fines or the initiation of prosecution by the CCM. This requirement is to ensure that companies provide adequate disclosures of information for the purpose of economic decision-making of the users. 
The compliance rate is one of the benchmarks established and collectively agreed upon by most of the commonwealth countries for measuring the level of transparency by companies for the general public. The compliance rate represents the ratio of the total number of companies that submitted their annual returns to CCM to the total number of registered companies. In Malaysia, the compliance rates have increased by an average of 10 percent per year from 2003 to 2007 . The significant improvement is attributed to various initiatives undertaken by CCM, such as the relentless enforcement drive of 2007, which resulted in a 33.8 percent increase in the number of cases prosecuted. A total of 5,712 companies were prosecuted in 2006 compared to only 3,938 companies prosecuted in 2005 for offenses committed under the Companies Act 1965. Since the inception of CCM in 2003 until 2007, the trend of compliance rates has increased significantly. Figure 7 shows the compliance rates among the companies in Malaysia from 2003 to 2007 . Based on Figure 7, the compliance rate has increased steadily from 41 percent in 2003 to 91 percent in 2007 . This reflects the achievement of CCM in its regulatory role over the reporting practice by companies in Malaysia.

Figure 7: Compliance Rate Trend Analysis

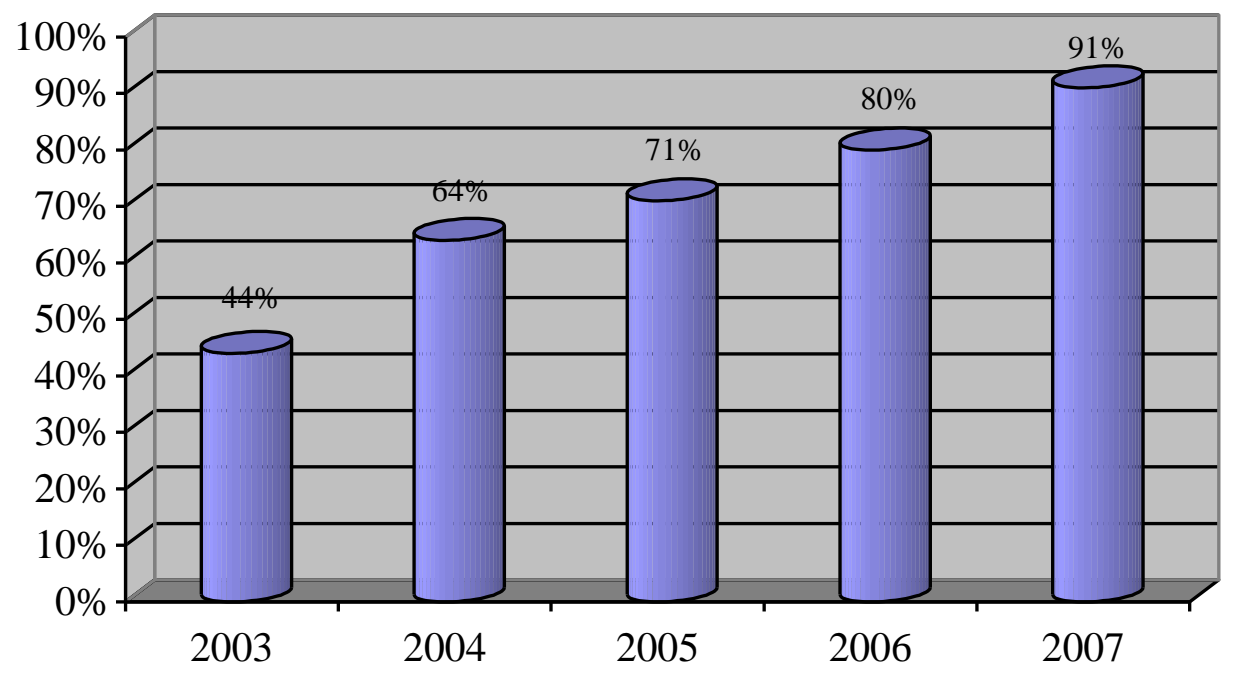

Source: CCM Annual Report 2007

The annual return submissions among companies in Malaysia are comparable with other commonwealth countries. Figure 8 shows the percentages of annual return submissions of Malaysian corporations and corporations in other countries. In general, the compliance rate by companies in many countries in the world is around 90 percent with the highest of 95 percent in the United Kingdom and the lowest of 89 percent in Hong Kong. In Malaysia, the compliance rate is 91 percent.

Malaysia has achieved a significant milestone by reaching the compliance rate of 91 percent in 2007, which placed Malaysian companies' compliance rates equal to the rates of foreign countries, such as Hong Kong, New Zealand, Singapore, and the United Kingdom. This significant attainment was largely attributed to the Balanced Enforcement Approach implemented by the CCM. This improvement was achieved by maintaining a balance between traditional enforcement activities and the education program of the company officers. The CCM is vigorously pursuing surveillance, inspections, investigations and prosecutions of offenses. CCM encourages a continuous awareness among the corporate community concerning the importance of compliance with the legal provisions. The CCM education and awareness initiatives have made a significant contribution toward achieving the improvement of compliance rate to 91 percent in 2007. 
Figure 8: Inter-jurisdiction Comparative Compliance Rate

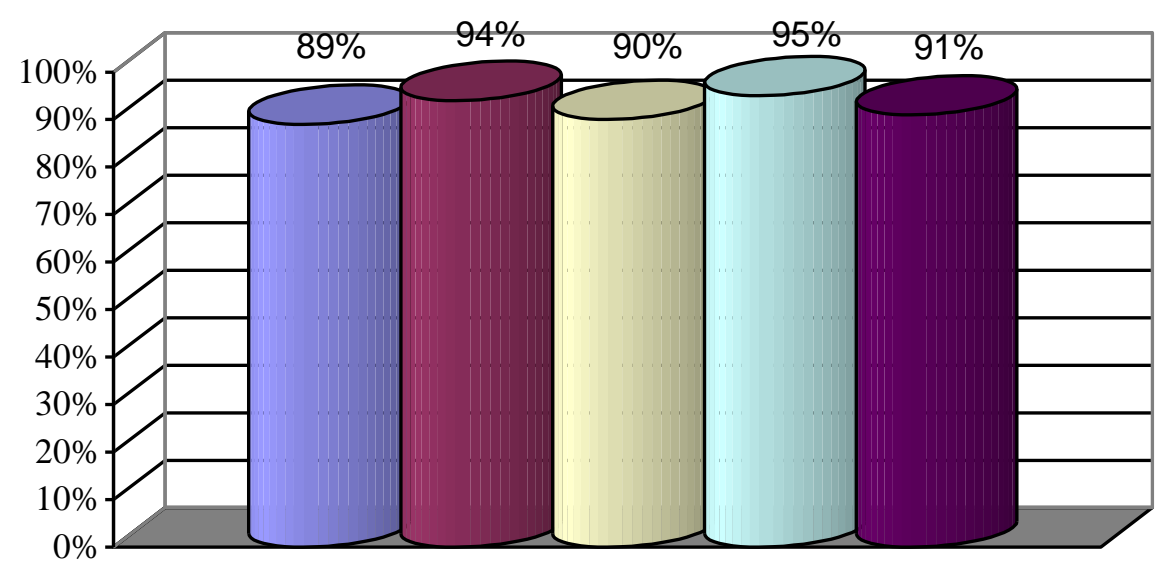

\begin{tabular}{|lll|}
\hline$\square$ Hong Kong (2006) & $\square$ New Zealand (2006) & $\square$ Singapore (2006) \\
$\square$ United Kingdom (2007) & $\square$ Malaysia (2007) & \\
\hline
\end{tabular}

Source: CCM Annual Report 2007

\section{CONCLUSIONS}

CCM has implemented various methods and programs in order for companies to achieve a certain standard of best practices of corporate governance. CCM has adopted the Balanced Enforcement Approach, which combines the sanctions of the law with the awareness and education program that is encouraged among the government agencies and companies. CCM resources have been increased in order to cope with regulatory activities over the increasing number of companies registered with CCM. The number of physical inspections of companies, investigation cases and prosecution matters in the courts for various offenses under the Companies Act 1965 has increased significantly since its interception in 2003.

The compliance rates on corporate governance disclosure requirements among companies in Malaysia have gradually improved. This is evident from the current level of compliance rates on corporate governance disclosure, which is comparable to those in other countries. CCM has improved its effectiveness in promoting and strengthening the level of corporate governance among Malaysian companies. CCM continues to improve its education and enforcement activities in increasing the compliance rate and best practices of corporate governance in order to become comparable with other countries.

This report reveals that CCM has made substantial progress in terms of promoting and enforcing the rules and good practices of corporate governance. A rating system should be established by the CCM as a benchmark in order to measure the level of corporate governance practices among the companies in Malaysia. This rating system would also benefit domestic and foreign investors by facilitating their decision-making processes on companies in Malaysia (Malin, 2003). As a regulator, the CCM should continue to reform for improving the laws and codes of best practices of corporate governance among Malaysian companies. CCM is expected to reform its existing laws and to restructure its litigation and regulatory systems by introducing a stronger legal enforcement. A strong and robust legal, regulatory and enforcement structure has to be put in place in order to arrive at the aspiration of good governance (Webb, 2006).

For the corporate governance legislative framework to function properly, education and enforcement become absolutely necessary. Educational programs should be expanded to meet the minimally acceptable level offset by the code of corporate governance in Malaysia. The CCM should promote voluntary professional and 
ethical management procedures among corporate directors, officers and employees. The corporate governance legislative framework must be adequately enforced by government in order to establish effective corporate governance within companies. It is now accepted by many leading companies that 'good corporate governance' encompasses an inclusive, stakeholder-based approach and is compatible with, and even a driver of, a long-term maximization of shareholder value (Mason and O’Mahony, 2008).

\section{REFERENCES}

1. Sarji, A. (Tan Sri Dato Sri, Dr.). 2007. Ethics and accountability for good governance in the private sector and the civil service. An Essay on Islamic Management and Organizational Performance Measurement.

2. Companies Commission of Malaysia (CCM) Annual Report. 2007. Companies Commission of Malaysia, Kuala Lumpur.

3. COMTRAC. 2008. Understanding and application of good corporate governance. Training Notes for Train the Trainer Training program on Technical Content for Corporate Directors Training Program. Companies Commission of Malaysia. pp. 14-15.

4. Companies Commission of Malaysia Act of 2001 (Act 614). 2001. Percetakan Nasional Malaysia Berhad, Kuala Lumpur, Malaysia.

5. Companies Act of 1965 (Act 125) (Revised 1973). 2008. LexisNexis Publication. Kuala Lumpur, Malaysian.

6. Corporate Directors Training Program. 2007. Companies Commission of Malaysia. COMTRAC Application Form, Kuala Lumpur.

7. Devi, S. 2003. Corporate governance as an evolutionary process: A Malaysian perspective. United Nations Conference on Trade and Development. p. 53.

8. Johnson, D. J. 2003. White paper on corporate governance in Asia. OECD Publication.

9. Malaysian Code of Corporate Governance. 2007. Securities Commission of Malaysia.

10. Malin, C. 2003. The relationship between corporate governance, transparency and financial disclosure. United Nations Conference on Trade and Development. p. 1.

11. Mason, M. and J. O'Mahony. 2008. Post-traditional corporate governance. Journal of Corporate Citizenship, (Autumn) 31: 31-44.

12. OECD (Organisation for Economic Cooperation and Development). 2004. OECD Principles of Corporate Governance, Paris, France: OPCD.

13. Rahman, R.A. 2006. Effective corporate governance. University Publication Centre (UPENA). Universiti Teknologi MARA, Malaysia (UiTM).

14. Shim, D.S. 2006. Governance in the markets: Malaysian perspective. Journal of Financial Crime, 13 (3): 300-322.

15. The Star. 2007. Balance enforcement. Star Publication. Malaysia. (October).

16. Webb, M. 2006. Corporate governance: challenges, opportunities and returns. The Qatar Corporate Governance Conference, September 13-14, Doha, Qatar. 
NOTES 